IDEA - Studia nad strukturą i rozwojem pojęć filozoficznych $\mathrm{XXIX/1}$ Białystok 2017

Victor Ogheneochuko Jeko, George Uzoma Ukagba

(Benin, Nigeria)

\title{
PHENOMENOLOGICAL-HERMENEUTIC APPROACH TO COMMUNICATIVE ACTION AS THE NORMATIVE FOUNDATION OF DEMOCRATIC SOCIETY
}

\section{Introduction}

Habermas's communicative theory revealed the normative foundation of democratic society. It revealed need for international integration through reasoned communication. Habermas's phrase logical terminology "communicative action" and deliberative democracy are geared towards addressing the normative foundation of human society and to grasp the basic complexities of human political society.

Habermas's communicative theory and his political ideology revealed the conceptual justification of the common good in human society in order to ensure normative co-existence among human beings in their immediate society. One fundamental element that distinguishes Habermas's communicative political theory from other contemporary scholars, is that his work stand the test of time due to his ingenuity in addressing global world order or global peace and ethics in ensuring an emancipated global society.

Habermas's work is greatly connected to other scholars such as Kant, Plato, Aristotle, Hobbes, Locke, Rousseau, and Rawls.

Habermas's work revealed the need for human integration, human emancipation and collective decision making. His communicative theory is referred to as an applied political ethics. It reveals the need for the co-catenation of ethics 
and politics to address the complexities of human society. Habermas's communicative political theory is all about the need for global order.

\section{Phenomenological - hermeneutic approach to habermas's communicative action}

Many scholars have criticized Habermas' theory of communicative action due to its inability to grasp complexities of present democratic realities. Communicative action has been seen as the normative foundation of democratic society. Habermas reflected on the possible solution to the present political instability facing our contemporary human society. He saw this solution to the problem of contemporary democratic politics and in reasoned communication. Habermas has advocated for 'reason' as the tool for communicative interaction. This concept of 'reason' as a tool for communication presupposed rational dialogue and social change in our international system. What comes first is reason; human proper way of reasoning devoid of immaturity. The problems of global justice, universal human rights and global citizenship can only be resolved by international interaction through reasoned communication.

Habermas' Theory of Communicative Action presupposed undistorted communication, and political goals and the procedural justification of deliberative democracy or dialogic democracy. According to George Ritzer and Jeffrey Stepnisky, "for Habermas the political goal is a society of undistorted communication action".

However, the phraseologies (communicative action theory and deliberative democracy) are simply tackled intelligently to address the contextual justification of these concepts in good society and the intelligible network of social interaction. According to George Ritzer and Jeffrey Stepnisky, "social interaction exists first within social groups...social structure emerges from social interaction, but once this occurs, social structures have a separate existence that affects the process of interaction"2.

${ }^{1}$ George Ritzer and Jeffrey Stepnisky, Sociological Theory, (New York: Mc-Graw Hills Higher Education, 2014), p. 293.

2 Ibid., p.414. 
Communicative action has been human form of social activity while communicative rationality is reasoned communication. Habermas' theory of communicative action correlated with his contemporary democratic theory. Accordingly, John Hoffman and Paul Graham believed that "Jurgen Habermas offers the best contemporary statement of logical entailment" . Habermas shared the same conception of basic human rights with the Rawlsian conception of justice as fairness which has global contemporary relevance. Accordingly, John Hoffman and Paul Graham believed that "the growth in consciousness of human rights is one of the achievements of communicative rationality" ${ }^{4}$. Contemporary political philosophy has been all about the exploring of political ideas in our practical everyday life which showcased action and re-thinking of our new world order. According to lain Mackenzie, "political philosophy, therefore, is not just thought, but also action: or, better yet, it is both thought and action together"

Now, the problematic questions are:

1. Is reasoned communication really a solution to our global crises?

2. Can we say that reasoned communication can really present anything truly new?

3. Is there any way the critique of reason can be subverted?

4. Is there any critique of reason within reason itself?

5. What are the limits of rationality in our contemporary world?

6. What are the present solution (s) to our contemporary global crises especially the plethora of crises in North Africa and Middle East?

7. Can dialogue play any significant role and can it bring to the fore social change and bring about anything new at the national and international level?

8. Does deliberative democracy have any thing to offer or contribute to our enlightened democratic vision or human betterment?

9. Does Habermas' thought have the ability to grasp the complexities of democratic society?

10. What are the major constraints to communicative freedom of the individual and communication community?

${ }^{3}$ John Hoffman and Paul Graham, Introduction to Political Theory, Second Edition, (England: Pearson Education Limited, 2009), p. 421.

${ }^{4}$ Ibid., p. 422.

${ }^{5}$ Iain Mackenzie, Politics: Key Concepts in Philosophy, (2009), p.164. 
11. What are the ideological distortions to the system-life-world or what we may refer to as the thesis of internal colonization?

12. How is social order really possible in human contemporary society?

The essence of communicative action theory in political philosophy has been to guarantee contemporary ideal political order. The task in this intellectual discourse is the firmer understanding of the conceptual analysis and theoretical framework of communicative rationality and its continued contemporary relevance to normative ideal social order and new world order. The tenacity for good human dialogical relation provided broad range of ethical implication and discursive social practice. We shall circumscribe the conceptual analysis of communicative action theory in Habermas' political philosophy within the ambit of logical entailment and normative ideal social order. According to John Hoffman and Paul Graham, "the rational entailment argument identifies certain conditions for the existence of social order and from those conditions maintained that there are certain standards of treatments which all societies should respect" ${ }^{6}$.

Communicative action theory represented form and substance positing the real philosophical justification of social interaction. According to Joan Ferrante, "social interactions are everyday events in which at least two people communicate and respond through language and symbolic gestures to affect one another's behavior and thinking"7. Another pressing contemporary issue to be looked at included the critique of Habermas' philosophy from the perspective of communicative stand point and the differentiation based theory of social systems developed by Niklas Luhmann a student of Talcott Parson.

The purpose of this intellectual discourse has been to bring to the foreground the theoretical and practical implications and the normative frameworks of the Habermasian theory of communicative rationality to contemporary human society. The theory of communicative rationality demand criticizable validity claims. The Habermasian tradition represented communicative competence and communicative skills of human association (speech skills and social interaction). Language or what we may call 'ideal speech situation' guaranteed the need

\footnotetext{
${ }^{6}$ Op. cit., p. 421.

${ }^{7}$ Joan Ferrante, Sociology: A Global Perspective, Fifth Edition, (USA: Wadsworth \& Thomson Learning, 2003), p. 142.
} 
for human social interaction. Social interaction plays a crucial role in human activity.

Furthermore, one cardinal purpose of this research is to bring to the foreground the indispensability of dialogue method and its role in solving the crises of humanity in order to ensure new world order or global peace and the strategy of stemming out global terrorism. Dialogue, invariably, has been the basis of normative ideal global order. Habermas' discursive ethics showcased his theoretical contribution to cosmopolitan politics. Put differently, cosmopolitan politics simply means global politics and the role of the indispensability of dialogue to international system. Habermas has been so committed to global world order and his contemporary political philosophy has come to stay with us in our search for contemporary ideal political order. Habermas' theory of communicative action correlated with his discourse ethics, theory of law and democracy.

Moreover, it is germane to extrapolate that the philosophical imperative for dialogical philosophy cum existential import are anchored on the discursive ethics of Habermas, and a synergy should take place between social system and lifeworld to prevent any ideological breakdown or distortion or the internal colonization of human society. Society is not a free-rider system, so to speak, but it is governed by customs, traditions, rules and regulations, values and norms. Habermas' theory of communicative action is invariably and undoubtedly predicated on the normative structures of interpersonal linguistic communication skill or strategy. Habermas considered his major contribution to be the development of the concept and theory of communicative reasoning or communicative rationality, which distinguished itself from the rationalist traditions by locating rationality in the structures of interpersonal linguistic communication rather than in the structure of the social world. Habermas has been fondly referred to as a radical or social reformist who has dovetailed into the theoretical framework, contextual justification and conceptual clarification of critical social theory.

The significance of Habermasian philosophical tradition has been that his philosophy cut across political philosophy, law, political science, sociology, linguistics, communication, psychology, and ethnology. Habermas' philosophy has had a continued relevance to our contemporary normative ideal social order, social structures, whereby bringing in cognizance the internal logic or logical mechanisms that governed our social normative structures of our system-lifeworld or society which has been bastardized, balkanized or mesmerized. 
Interaction is not feasible in an atmosphere of dog-eat- dog society. According to George Ritzer and Jeffrey Stepnisky, "interaction is the process in which the ability to think is both developed and expressed"8. Society cannot progress rapidly in an atmosphere of rancour, acrimony and bloodletiness. This research is expected to prove so candidly that theory can be converted into practical demonstration and workable form if such theory is well articulated, well natured and nurtured. The pragmatic study of Habermas' philosophy served as a kaleidoscope or eye-opener for the indispensability of dialogue and the rationalization of society by re-awakening in the mind of the people, the sense of freedom and responsibility as the hallmark of societal progress. It reminded us the sense of purposive rational activity, constitutional patriotism, honesty of purpose, purity of intention or motive, enhancing the idea of the common good and provided a strong normative foundation of goodwill in rational society. Finally, Habermas' philosophy has been 'ipso-facto', the centre-point of continuous learning process of social activity between our moral obligations and others. Many of us have loss the sense of reasoning, meaning and our freedom. Our reasoning faculty has been beclouded by high level of irrationality, carnivorous tendencies and no sense of awe for human life and we have virtually lost our sacredness for humanity. Democratic public life cannot develop where matters of public importance are not discussed by citizens in an atmosphere of free and open communication or discursive communication.

An 'ideal speech situation' required participants to have the same cognitive capacities of discourse of social equality and their words are not confused by ideology or other human errors. In this version of the rational consensus coherence theory of truth, Habermas maintained that truth is what would be agreed upon in an 'ideal speech situation'. Habermas has expressed optimism about the possibility of the revival of the public sphere.

In this discourse we shall adopt the phenomenological and the hermeneutic methods. The work used the method of phenomenology and hermeneutics because it exposed the understanding of Habermas' theory of communicative action and democratic society from a more workable approach. Habermas' theory of communicative action presupposed the phenomenological method because phenomenology has to do with the revealing of the hidden goals in things. Phe-

\footnotetext{
${ }^{8}$ George Ritzer, Sociological Theory, Second Edition, (2014), p. 350.
} 
nomenology reflected bracketing of our prevailing biases or prejudices in order to see things as they are.

The purpose of the phenomenological approach has been to illuminate the specific, and to identify phenomena and how they are perceived by the actors in a situation. In the human sphere, this normally translated into gathering 'deep' information and perceptions through interviews, discussions and participations observation, and representing it from the perspective of the research participant. Phenomenology is concerned with the study of consciousness and experience from the perspective of the individual, 'bracketing' taken- for- granted- assumptions and the usual ways of perceiving things in the world. Epistemologically, phenomenological approaches are based on a paradigm of personal knowledge and subjectivity, and emphasized the importance of personal perspective and interpretation. Phenomenological research has overlapped with other essentially qualitative approaches including ethnography, hermeneutics and symbolic interactionism. My major interest in this work has been to embark on the method of phenomenological hermeneutics. It is the merging or conglomeration, the adoption of phenomenology and hermeneutics in research in order to get the hidden goals or truth in things as they are.

Phenomenological methods are particularly effective at bringing to the foreground the experiences and perceptions of individuals from their own perspectives, and therefore aimed at challenging structural or normative assumptions. Adding an interpretive dimension to phenomenological research, enabling it to be used as the basis for practical theory, allowed it to inform, support or challenge policy and action. A variety of methods can be used in phenomenologically based research, including interviews, conversations, participant observation, action research, focus meetings and analysis of personal texts. If there is a general principle involved an indepth analysis or maximum depth, in practice constrained by time and opportunities to strike a balance between keeping a focus on the research issues and avoiding undue influence by the researcher. Phenomenological approach exposed taken- for- granted- assumptions and challenged a comfortable status quo.

According to Stan Lester:

Phenomenological approaches are good at surfacing deep issues and making voices heard. This is not always comfortable for clients or funders, particularly when the research exposes taken-for-granted- assumptions or challenges a comfortable sta- 
tus quo. On the other hand, many organizations value the insights which a phenomenological approach can bring in terms of cutting through taken- for granted- assumptions, prompting action or challenging complacency. ${ }^{9}$

Human reality is based on observation, consciousness and experience. Phenomenological method has been clearly defined as that method that has to do with the method of analysis showcasing the fact that the whole is dissected into parts and these parts are critically put together for meaningful understanding. Things are broken into parts and these parts are put into a coherent whole. Phenomenology has been the study of structures of consciousness as experienced from the first person point of view. The central structure of an experience is its intentionality and it is that which is directed towards something. Phenomenology is the study of structure of consciousness and experience. These two methods are adopted for the sole purpose of ensuring the best possible, the aim or objective of this intellectual discourse.

Furthermore, we shall also adopt the hermeneutic method which has to do with the science of interpretation. Hermeneutic philosophy envisaged how understanding is possible. The origin of the term "bermeneutics" (from the Greek hermeneutikos) bears an obvious reference to Hermes, the messenger god of the ancient Greeks. Hermeneutic philosophy attempt to foster understanding and rendered what is unclear clear. Hermeneutics has been the science of the interpretation of meaning. Habermas' critical social theory is contemporary hermeneutics characterzed by observation, pragmatics, critical and radical philosophy. Critical theory envisaged interpretation and interpretation involved entering into the interpretation of normative core of human communication community; meaning here operates and is to be found within the historical contexts of the interpreter and interpreted. When we say that something is critical we mean the purpose of interpretation here is emancipatory; conventional wisdoms within communities are challenged in order to address potential power asymmetries or irregularities or illogicalities. Paul Ricoeur's phenomenological hermeneutics presented a set of basic normative core or methodological principles to guide praxis. The concept of the hermeneutic circle of understanding presented an overview of social development process. It followed, then, that this conceptual framework of the hermeneutic circle of understanding required recognition if a

9 Stan Lester, An Introduction to Phenomenological Research,' (Tauton UK: Stan Lester Developments, 2009), p. 4. 
phenomenon such as the social development process is to be fully understood. Social actors must begin to explore the Gadamerian 'fusion of horizons' and that of mutual understanding of the phenomenon of social development.

According to Georgie Wanke,"hermeneutics is a tradition of thought that deals with the understanding of interpretation of meaning"'10. Broadly speaking, the hermeneutic circle reflect the critical understanding of our existential condition of our system-life-world. Georgie Wanke opined that, "the hermeneutic circle becomes a historical fact and an element of our existence" ${ }^{11}$. Strictly speaking, the hermeneutic method is associated with philosophers such as Gadamer, Derrida, and Levinas, we will apply the Gadamerian kind of hermeneutic method as far as this work is concerned.

We must acknowledge that we are finite and historical beings and that, as long as we are concerned, our understanding will be partial and interpretive. Jaegwon Kim ansd Ernest Sosa asserted that "hermeneutics recognizes the contextual and pragmatic character of all claims of knowledge" ${ }^{12}$. Hence, "it is concerned with edification, with a conversation in which we can enrich our various conceptions of ourselves and the world by trying to understand those of others... hermeneutic, here reaches its fullest extent thus" ${ }^{13}$.

Communicative action means mastering the world reality and it showcased the establishment of interpersonal relation. Communication has been very crucial as far as human association is concerned. According to David Jary and Julia Jary, "communication(s) means the (1) imparting or exchange of information. Communication may be verbal or non verbal, intended or unintended (2) the message(s) or unit(s) of information communicated (3) the means of communication" ${ }^{14}$. Thomas McCarthy posited that "communicative action is a social activity. According to David Jary and Julia Jary, "communicative competence is the means, including the rules, by which persons sustain communicative exchanges and interactions with others within a world's community. The term 'communication' is coined by Hymes (1966) to focus attention on the skills and

${ }^{10}$ G. Wanke, Hermeneutics in Jaegwon Kim \& Ernest Sosa (Eds). A Companion to Metaphysics, (Oxford: Blackwell Publishers, 1995), p. 206.

${ }^{11}$ Ibid., p. 207.

${ }^{12}$ Loc, cit.

${ }^{13}$ Loc, cit.

${ }^{14}$ David Jary and Julia Jary, Collins Dictionary of Sociology, (2000), p. 92. 
knowledge involved in human communication... It reflected on the limitations in linguistics of concentration mainly on syntactic competence" 15 .

According to David Jary and Julia Jary:

The human capacity for communication, especially through language, is far more extensive than that of any other animal. The capacity to communicate across time and space has expanded enormously in modern times with the invention of writing, printing, electronic communications- telegraphy, telephone, radio,-and media of mass communications, as well as, the mechanization of transportation. A reduction of what geographers refer to as the friction of distance has been particularly evident in the $20^{\text {th }}$ century in the capacity to send messages over long distances at great speed. This has many implications, not least the increased capacity for social control this makes possible for the modern state. ${ }^{16}$

Nevertheless, Habermas' theory of communicative rationality exposed the criticizable validity claims: yes/no claims that are usually acceptable by the human society.

Political philosophy is the study of topics such as politics, liberty, justice, property, rights, law, and the enforcement of a legal code by state authority. Habermas' theory of communicative action heralded his political philosophy.

The indispensability of dialogue in Habermas' philosophy guaranteed the acceptability of dialogic democracy and the errant rejection of an ideology that is dogmatic that allowed no debate such as fundamentalism. Habermas' contemporary political philosophy does not presuppose a free- rider- system (a social system whereby anything goes without being checked by laws or moral precepts).

The idea of communicative action theory will be clarified in this intellectual discourse because according to the Ayerian tradition, the clarification of concept is the sole business of philosophy. Dialogic or dialogical philosophy is a twofold issue and it exemplifies relational analysis or dialectical process. This method started from the normative assumption that every utterance has an addressee. The central question is: To whom is the person speaking?

However, the address is rather a multiplicity of others, a complex web of invisible or cob-web of human interaction whose presence can be traced to in

\footnotetext{
${ }^{15}$ Ibid.

${ }^{16} \mathrm{Ibid}$.
} 
the content, flow and expressive elements of the utterance. It means connection between two persons or things. The word "dialogic" is ambiguous. It has its relevance in various fields; the psychology of globalization, educational psychology, media psychology, cultural anthropology, developmental psychology, social constructivism, philosophy, Jungian psychoanalysis, cultural psychology, social work, experimental social psychology, brain science, psychopathology, and psychotherapy. The topic of mediated dialogue in a global age has been at the heart of a special issue on cultural identity and the sacredness of our humanity. Religion is the transcendence within. Transcendence means the movement of consciousness of being. In this connection, Alexander Moseley opined that "consciousness generally implies being able to be aware of one's surroundings" ${ }^{17}$. Habermas is very critical about the mode of production called capitalism. Etymologically, philosophy was derived from the Greek word philo sophia. When joined together it means the love of wisdom. Philosophy is systematic, logical, rational and theoretical. It is an open system of study and not a closed-system. Philosophy is said to be the peak or height or mother of all disciplines. Etymologically, the term "democracy" is derived from the Greek words "demos" (people) and "kratia" (power) which simply means people and power respectively or put conversely the people's power. Literally, it could be said to be people's power or power of the people. The people are the source of state's sovereignty. Democracy is not a new system of government. It is as old as humanity itself. In every society, the system of social control has some democratic principles, respecting some popular normative ideals, having a measure of popular support, and goodwill. Democracy presupposed the voluntary free intelligence and social activity of men in a harmonized and systematically coordinated manner.

The term 'deliberative democracy' was originally coined by Joseph. M. Bessette in his 1980 work "Deliberative Democracy: The Majority Principle of Republican Government". The James Fishkins model of deliberation is characterized by information, substantive balance, diversity, conscientiousness, and equal consideration. Finally, Habermas' contemporary political philosophy is radical democracy or dialogic democracy characterized by liberal society and demanded more political participation, contemporary debate and discussion or public conversation.

${ }^{17}$ A. Moseley, $A$ to $Z$ of Philosophy, (London: Continuum International Publishing Group, 2008), p. 36. 
Habermas' contemporary political philosophy emphasized the need for global order and a more reasoned communication (communicative discourse) on public issues.

According to Mitchell Stephens:

The key word in Habermas's political vocabulary, however, is democracy. He often has in mind a more "radical democracy" than that with which most Americans are familiar. In the phrase 'government by and for the people', Habermas places much more emphasis on the 'by' than most of us normally would", McCarthy explains. He wants less unthinking nationalism and more reasoned communication on public issues. He wants more participation by citizens in government processes, in political parties, in economic decisions- a larger "public sphere" than can be found in any existing society. Habermas wants more debate and discussion ${ }^{18}$.

Habermas' philosophy transcended national and global dimensions or cosmopolitan politics. Political philosophy involved a creation of norms and forms of social interaction. According to Iain Mackenzie, "political philosophy involves the creation of new forms of norm governed social interaction" ${ }^{19}$.

Habermas' philosophy of reasoned communication has been an intellectual contribution to global terrorism. Terrorism is an elusive concept. It constituted an imminent danger to the project of humanity. Hence, there is this need for global dialogue or global interdependence. John Hoffman and Paul Graham opined that "terrorism is the use of political violence in situations in which people have reasonable avenues of peaceful protest" 20 . The indispensability of dialogue in Habermas' communicative action theory showcased his contemporary political philosophy. According to John Hoffman and Paul Graham, "theories of global justice are concerned with what obligations nation-states have to one another and obligations citizens of different nation-states have to one another" ${ }^{21}$. Habermas' contemporary political philosophy is all about human emancipation, social integration and his enlightenment democratic vision revealed an emancipated global society. According to John Hoffman and Paul Graham

${ }^{18}$ Stephens Mitchell, The Theologian of Talk; "The Question is whether Justice Exists and Reason can benefit Society”. (Los Angeles Times Magazine, October 23, 1994), p. 10.

${ }^{19}$ Iain Mackenzie, Politics: Key Concept in Philosophy, (2009), p.164.

${ }^{20}$ John Hoffman and Paul Graham, Introduction to Political Theory, (2009), p. 501.

${ }^{21}$ Ibid., p.497. 
emancipation is "the capacity of people to act freely and thus govern their own lives"22.

Habermas' contempoarary political philosophy encapsulated the basic normative core of human rights. According to John Hoffman and Paul Graham, "human rights means the entitlement to treatment which it is claimed individuals have simply by virtue of being human"23.

\section{Recommendations}

Habermas's communicative political theory reveals the clarion call for human existential relationship in a manner that will guarantee global peace.

Habermas's communicative ethics should be used as an antidote for political theory or ethics ought to be seen as an antidote for political stability. Ethics should be an avenue or a platform for addressing or grasping the complexities of human existential-political challenges.

Ethics serves as a foundation for political stability and human progress or human social integration. Communicative ethics serves as a yardstick for the propagation of human rights according to the Habermasian tradition. The Habermasian tradition could serve as a yardstick or a platform for global justice and the rationalization of society.

\section{Conclusion}

Habermas's contemporary political philosophy vis-à-vis his communicative theory could serve as an antidote for global world order or global integration. Habermas's concern for human integration revealed the need for an emancipated global society.

Habermas's vision for an emancipated global society is all about human freedom and the promotion or the propagation for human rights all over the globe. Habermas's vision for an emancipated global society call for the institutionalization of democracy and the need for international peace and justice.

\footnotetext{
22 Ibid., p. 496.

${ }^{23}$ Ibid., p. 498.
} 
Habermas's contemporary political philosophy and his communicative theory revealed the need for a democratic vision for human global justice. Habermas's democratic vision and communicative democracy is encapsulated in mastering the world and it is all about problem solving mechanism and human societal progress or the rationalization of society. Habermas's communicative theory revealed the need for collective decision making, the institutionalization of social justice in democratic society and the frantic efforts to ensure the imperative of dialogue in human political participation.Habermas's communicative political theory is encapsulated in a basic normative core of human rights and global justice, peace and order.

\section{Summary}

This paper reflected on the need to address the problem of human co-existence and the need for ensuring that political instability is simply addressed. The normative foundation of human democratic society has never been on a solid bedrock due to human frailties.

This paper seeks the need to address this human impasse from a more phenomenological and hermeneutical approach by using Habermas's communicative theory as a normative foundation for addressing this global challenges. This paper therefore adopts a method of analysis, phenomenology and hermeneutics to address the democratic vision of human normative foundation of social order.

This paper therefore concluded that communicative action serves as a prelude for the normative foundation of human democratic institution. Habermas's contemporary political philosophy vis-à-vis his communicative theory could serve as an antidote for global order or social order.

Key words: democracy, society, social order, philosophy, phenomenology, Habermas

\section{Bibliography}

Ferrante, Joan, Sociology: A Global Perspective, Fifth Edition, (USA: Wadsworth \& Thomson Learning, 2003), p. 142.

Hoffman John and Graham Paul, Introduction to Political Theory, (2009), p. 501.

Hoffman, John and Graham, Paul, Introduction to Political Theory, Second Edition, (England: Pearson Education Limited, 2009), p. 421.

Jary, David and Jary Julia, Collins Dictionary of Sociology, (2000), p. 92.

Lester, Stan, An Introduction to Phenomenological Research,' (Tauton UK: Stan Lester Developments, 2009), p. 4.

Mackenzie, Iain, Politics: Key Concept in Philosophy, (2009), p.164.

Mitchell Stephens, The Theologian of Talk; "The Question is whether Justice Exists and Reason can benefit Society". (Los Angeles Times Magazine, October 23, 1994), p. 10. 
Moseley, A., A to Z ofPhilosophy, (London: Continuum International Publishing Group, 2008), p. 36.

Ritzer, George and Stepnisky, Jeffrey, Sociological Theory, (New York: Mc-Graw Hills Higher Education, 2014), p. 293.

Ritzer, George, Sociological Theory, Second Edition, (2014), p. 350.

Wanke, G., Hermeneutics in Jaegwon Kim \& Ernest Sosa (Eds). A Companion to Metaphysics, (Oxford: Blackwell Publishers, 1995), p. 206.

Victor Ogheneochuko Jeko., Ph.D

Dr. George Uzoma Ukagba, Ph.D. Associate Professor, Department of Philosophy, University of Benin, Nigeria. 